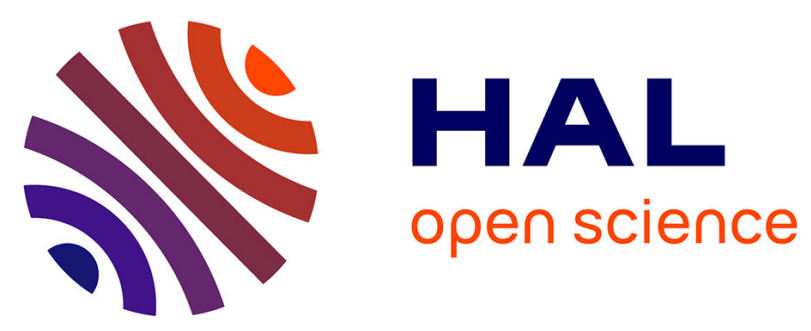

\title{
Experimental investigation of the hygrothermal performance of a new biocomposite material at wall scale
}

Nawal Chennouf, Boudjemaa Agoudjil, Abderrahim Boudenne, Karim Benzarti, Fethi Bouras

\section{- To cite this version:}

Nawal Chennouf, Boudjemaa Agoudjil, Abderrahim Boudenne, Karim Benzarti, Fethi Bouras. Experimental investigation of the hygrothermal performance of a new biocomposite material at wall scale. THERMOPHYSICS 2018: 23rd International Meeting of Thermophysics 2018, Nov 2018, Smolenice, Slovakia. pp.020012, 10.1063/1.5047606 . hal-03088988

\section{HAL Id: hal-03088988 \\ https://hal.science/hal-03088988}

Submitted on 27 Dec 2020

HAL is a multi-disciplinary open access archive for the deposit and dissemination of scientific research documents, whether they are published or not. The documents may come from teaching and research institutions in France or abroad, or from public or private research centers.
L'archive ouverte pluridisciplinaire HAL, est destinée au dépôt et à la diffusion de documents scientifiques de niveau recherche, publiés ou non, émanant des établissements d'enseignement et de recherche français ou étrangers, des laboratoires publics ou privés. 


\title{
Experimental investigation of the hygrothermal performance of a new biocomposite material at wall scale
}

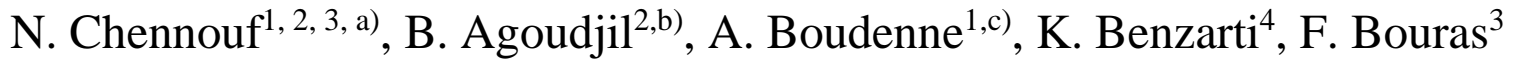 \\ ICERTES, Université Paris Est Créteil Val de Marne, 61 Av. Du Général de Gaulle, \\ 94010 Créteil Cedex, France; \\ 2 LPEA, Université Batna 1, Les Allées 19 Mai Route de Biskra Batna, Algerie; \\ 3University EchahidHammaLakhdar El-Oued, PO Box 789 El-Oued, Algerie; \\ 4IFSTTAR - Département Matériaux et Structures 14-20 Bd Newton - Cité Descartes \\ 77447 Marne-la-Vallée Cedex 2 \\ a) chennouf-nawel@ hotmail.com \\ b) b.agoudjil@yahoo.fr \\ c)boudenne@u-pec.fr
}

\begin{abstract}
:
The present work aims to study the hygrothermal behavior at wall scale of a new biocomposite material made with concrete reinforced with natural fibers. The outdoor climate conditions were simulated using a climatic chamber on the one side of the wall, while the conditions of temperature and relative humidity on the other side of the wall were maintained at constant values. The temperature and relative humidity were monitored at different depths of the wall using sensors. Several hygric phenomena were highlighted such as homogeneous vapor diffusion and huge vapor pressure variations due to the evaporation-condensation and sorption-desorption phenomena. Besides, significant thermal and hygric inertia was observed through the Date Palme Concrete (DPC) wall. The response time of our biocomposite wall is relatively short for temperature variation compared to the humidity ones.
\end{abstract}

\section{KEYWORDS}

Hygrothermal, Thermal inertia, Moisture transfer, Biocomposites material, Wall scale

\section{INTRODUCTION}

Reducing energy consumption and green house gas emission in construction sector became very necessary to protect our environment [1]. In this context, many solutions were adopted, such as using eco-friendly building materials in terms of reducing raw and non-renewable materials consumption.

Hygroscopic materials such as wood and wood based materials that absorb and release moisture can be used to reduce effectively the relative humidity variations across the wall due to their low thermal conductivity and high moisture capacity, and thus, a significant level of comfort can be ensured with least energy consumption [2].

This work deals with the hygrothermal behavior at wall scale of concrete reinforced with Wastes of Date Palm Fibers (DPF). Focusing on the ability of materials to moderate cyclic variation of humidity and temperature, the hygric and thermal inertia of this material was investigated. 


\section{MATERIALS}

The tested wall is made of Date Palm Concrete (DPC) with $0.5 \mathrm{~m} \times 0.4 \mathrm{~m} \times 0.15 \mathrm{~m}$ of dimension. This biocomposite is consisting with ordinary mortar reinforced with $15 \mathrm{wt}$. \% of date palm fibers. According to our previous works, this formulation has shown interesting thermo-physical, mechanical [3] and hygric properties [4].

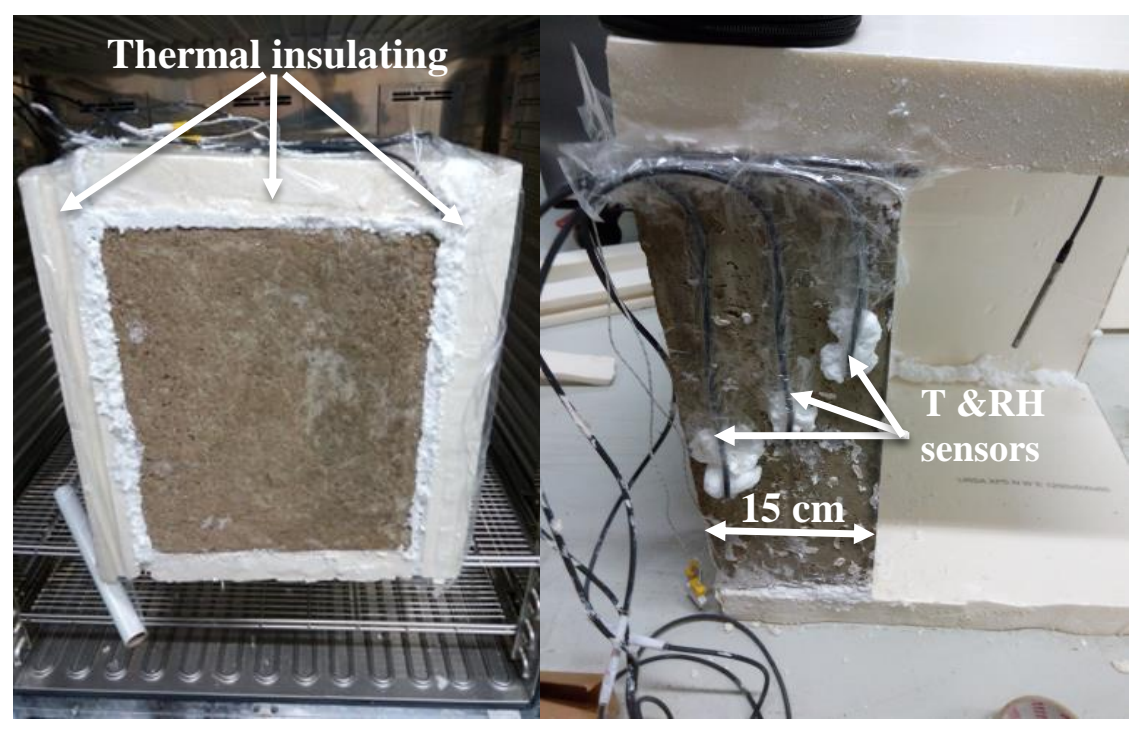

Figure 1: Investigated DPC wall.

The experimental device consists of a climatic chamber in order to simulate the outdoor climate conditions and another cell to simulate the indoor climate conditions.

The cell simulating the indoor climate allow to evaluate the performance of DPC wall through the response of this wall to cyclic and static variations of temperature and humidity generated by the climatic chamber "Memmert HPP $750 "$.

The second cell (mini chamber) was highly insulated hygrothermally on the 5 sides of the wall and only one side of the wall is concerned by the test as it is shown in figure 1. Firstly we used extruded polystyrene panel then with Glass wool for the thermal insulation.

Monitoring of temperature and relative humidity was performed in each room (climatic room and the mini chamber) and at different depths of the wall (at $x=3.5 \mathrm{~cm}, x=7.5 \mathrm{~cm}$ and $x=12.5 \mathrm{~cm}$ ) with DKRF400sensors. An overview of the experimental device, the used sensors and their locations are given in Figure 1.

In this work, we chose that the indoor conditions be not controlled (mini chamber). Whereas that the outdoor conditions are incrementally changed in order to create temperature and/or relative humidity gradients. Each step is followed by a conditioning phase at $50 \%$ and $23{ }^{\circ} \mathrm{C}$ until reached the equilibrium.

Table 1 summarizes the room conditions and the measurement strategy used.

Table1: Thermal properties of DPC wall

\begin{tabular}{lccc}
\cline { 2 - 4 } & Operating parameter & $\mathrm{T}\left[{ }^{\circ} \mathrm{C}\right]$ & $\mathrm{RH}[\%]$ \\
\hline \multirow{2}{*}{ Outdoor conditions } & Experiment 1 & 23 & $75 \rightarrow 33$ \\
\cline { 2 - 4 } & Experiment 2 & $40 \rightarrow 18$ & 50 \\
\hline
\end{tabular}




\section{RESULTS}

An isothermal experimental were performed according to the following protocol: after the initial state $\left(23^{\circ} \mathrm{C}\right.$ of temperature and $50 \%$ of relative humidity) is reached every where in the experimental device, the relative humidity of the outdoor set point was increased from 50\% to 75\% during 9 days then decreased from $75 \%$ to $33 \%$ during the following 9days. This protocol allows us to evaluate the buffer potential on cyclic variations of humidity of DPC wall. The measured values are shown in Figure. 2.

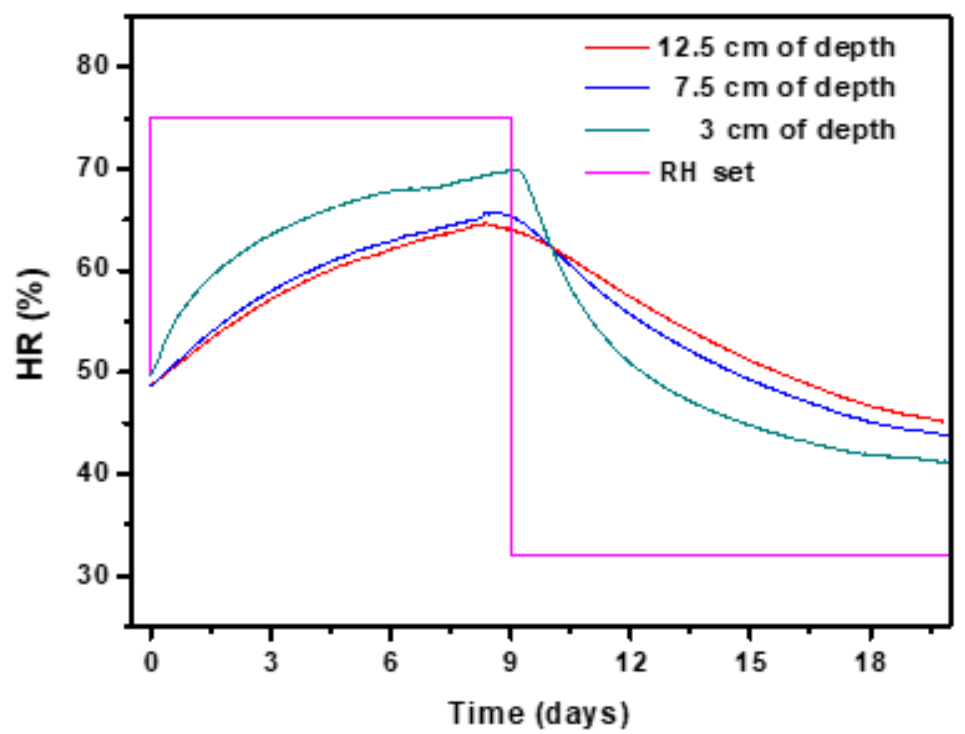

Figure 2: Relative humidity profiles.

Figure 2 presents the relative humidity variation over the entire experiment. Relative humidity measured within the wall starts to increase until reaching $70 \%$ at $3 \mathrm{~cm}$ of depth after 9 days of experiment, while at $7.5 \mathrm{~cm}$ and $12.5 \mathrm{~cm}$ of depth, the relative humidity reached only $65 \%, 64 \%$ respectively. On the other hand, similar behavior was observed at desorption phase, where the closest depth to the set point is affected significantly by the change in outside relative humidity conditions compared to the two other depths (i.e., $7.5 \mathrm{~cm}$ and $12.5 \mathrm{~cm}$, respectively).

Initially the indoor HR is at $50 \%$ and that of the outside is at $75 \%$, consequently a vapor transfer should take place. Nevertheless, as DPC exhibits an acceptable water vapor resistance factor [4], vapor diffusion occurs slowly.

The thermal response of the DPC wall was also investigated in our study. During this test, the device was conditioned at $23^{\circ} \mathrm{C}$ of temperature and $50 \% \mathrm{HR}$ for one week, then the external temperature was set at $40^{\circ} \mathrm{C}$ for 12 $\mathrm{h}$ and $18^{\circ} \mathrm{C}$ for the following $12 \mathrm{~h}$, the humidity was kept at $50 \%$. The temperature and relative humidity evolution within the wall was recorded periodically using sensors.

Figure 3 presents the temperature profiles at different depths: $3 \mathrm{~cm}, 7.5 \mathrm{~cm}$ and $12.5 \mathrm{~cm}$, respectively. It can be seenduring the heating period that the highest value of temperature (about $34^{\circ} \mathrm{C}$ ) was recorded at $3 \mathrm{~cm}$ of depth, while $32.5^{\circ} \mathrm{C}$ and $33^{\circ} \mathrm{C}$ of temperature were recorded respectively at $7.5 \mathrm{~cm}$ and $12.5 \mathrm{~cm}$.

In contrast, during the cooling period the temperature measured at $3 \mathrm{~cm}$ of depth reaches the set point value (i.e., $\left.18^{\circ} \mathrm{C}\right)$ whereas the others sensors placed at $7.5 \mathrm{~cm}$ and $12.5 \mathrm{~cm}$ showed the initial value of temperature $\left(23^{\circ} \mathrm{C}\right)$. From this result, we can calculate the phase shift and the peak damping as follows:

Table 2: Thermal properties of DPC wall

\begin{tabular}{lcc}
\hline \hline Proprieties & $\begin{array}{c}\text { Peak damping } \\
\left({ }^{\circ} \mathrm{C}\right)\end{array}$ & $\begin{array}{c}\text { Phase shift } \\
(\mathrm{h})\end{array}$ \\
\hline DPC wall & 7.5 & 12 \\
\hline
\end{tabular}


These properties can gradually dampen the amplitude of the thermal stress that across the wall. The obtained results show that DPC wall can moderate effectively the outdoor climate conditions, in particularly during the summer period where the temperature can reach $40^{\circ} \mathrm{C}$ or more.

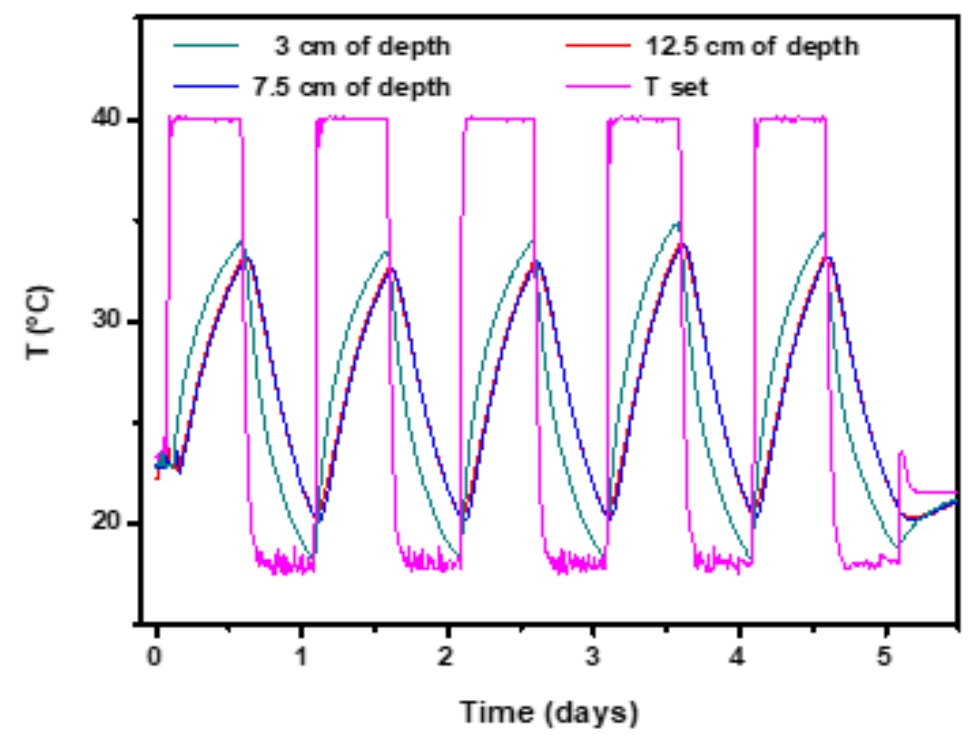

Figure 3: Thermal response of DPC wall.

\section{CONCLUSION}

In the present work, the hygrothermal behavior of a new biocomposite material was investigated at wall scale. Two experiments were carried out using a climatic chamber to assess the hygrothermal response of the tested wall. The results showed that our bio-composite material possesses an interesting hygric performance, which can contribute to moderate the variation of the relative humidity, thanks to the date palm fibers. Furthermore, according to the results our composite wall can also contribute to both attenuation and damping the peaks of outside temperature conditions especially in the summer period. Finally, the DPC exhibits a very good hygrothermal performance, which makes it suitable for thermal insulation applications and hygric regulation inside the buildings.

\section{RÉFÉRENCES}

[1] L. Perez-Lombard , J. Ortiz , C. Pout, "A review on buildings energy consumption information" Energy and Building, vol 40 pp 394-398 (2008)

[2] F. Asdrubali, F. D'Alessandro, S. Schiavoni, "A review of unconventional sustainable building insulation materials", Sustainable Materials and Technologies, pp. 1-17, 2015

[3] N. Benmansour, B. Agoudjil A. Gherabli, A. Kareche, A. Boudenne, "Thermal and mechanical performance of natural mortar reinforced with date palm fibers for use as insulating material in building," Energy and Building, vol. 81, pp. 98-104, 2014.

[4] B. Haba, B. Agoudjil A. Boudenne, K. Benzarti, "Hygric properties and thermal conductivity of a new insulation material for building based on date palm concrete," Construction and Building Materials,, vol. 154, pp. 963-971, 2017. 